\title{
Combustion modelling for forest fires: from detailed to skeletal and global models
}

\author{
P. A. Santoni \\ University of Corsica, UMR 6134 SPE, Corte, France
}

\begin{abstract}
This work aims to improve the understanding of the combustion of vegetative fuels. The degradation gases released by some Mediterranean species were determined. They mainly consist of $\mathrm{CO}, \mathrm{CH}_{4}, \mathrm{CO}_{2}, \mathrm{H}_{2} \mathrm{O}$ and other hydrocarbons. Then a study of the oxidation of a $\mathrm{CO} / \mathrm{CH}_{4} / \mathrm{CO}_{2}$ mixture was performed with a perfectly stirred reactor (PSR) at atmospheric pressure over the temperature range $773-1273 \mathrm{~K}$. Mole fraction profiles as a function of temperature were compared to the numerical predictions obtained with the PSR code from CHEMKIN II using the full mechanism GRI-Mech 3.0. A skeletal mechanism was developed from the full mechanism. It was tested for laminar flames obtained with samples of crushed Mediterranean species. Different skeletal and global mechanisms were also tested. The comparison between the simulated and predicted temperatures points out that the common assumption of carbon monoxide burning in air is not appropriate at this scale. Methane should be included in the modelling to perform reliable simulations. This result leads to the proposal of a simple combustion mechanism to be included in models of wildland fire.
\end{abstract}

Keywords: combustion modelling, degradation gases, forest fire.

\section{Introduction}

The understanding of the mechanisms that control the ignition and the spread of wildland fires is a major objective for the scientific community. Over the last fifty years, statistical, empirical and physical models have been proposed to simulate forest fires [1]. For ten years, physical models have tended to include more physical mechanisms. Among them, combustion kinetic was poorly investigated [2]. The combustible part of the devolatilization products is 
generally considered to be carbon monoxide burning in air [3], whatever the vegetation species. Although a detailed reaction mechanism (over three hundred reactions and 50 species) is possible for an accurate description of the chemistry, it is currently impractical for predicting wildfires due to the computational time. Thus, using simplified kinetics mechanisms is attractive. In this paper a modelling approach leading from full mechanisms to global models is presented. Gases released by the degradation of two pines (Pinus laricio, Pinus pinaster) and a heather (Erica arborea) were first determined thanks to a tube furnace. Then a perfectly stirred reactor (PSR) was used as a test environment to investigate the burning of these gases. The recorded molar fractions were compared to the prediction obtained with the PSR code from CHEMKIN II [4] using the full mechanism GRI-Mech 3.0 [5]. A skeletal mechanism was then developed from the full mechanism. This mechanism was tested to simulate laminar flames obtained from the burning of crushed forest fuels. A primitive variable formulation was used to solve the transient conservation equations obtained for the modelling of the laminar flames. A mixture representative of the degradation gases was also defined thanks to this mechanism. Then, due to the expansive computational time required, different skeletal and global mechanisms with fewer reactions were investigated. The aim was to provide a reliable kinetic mechanism allowing decreasing the computational time without losing accuracy to be included in model of fire spread. The paper is organized as follows. In the first section we present the study of the degradation gases, the PSR environment and the elaboration of the skeletal mechanism. In the second section, laminar flames experiments are exposed. The numerical method to simulate such flames and the comparison between the different skeletal and global mechanisms are detailed.

\section{From detailed to skeletal models}

\subsection{Degradation gases}

The tube furnace apparatus used as pyrolyser is shown in fig. 1. It is made of a cylindrical furnace $43.5 \mathrm{~cm}$ long with an internal diameter of $6.5 \mathrm{~cm}$. The reactor inside, is $86 \mathrm{~cm}$ long with an inner diameter of $5 \mathrm{~cm}$. Experiments were

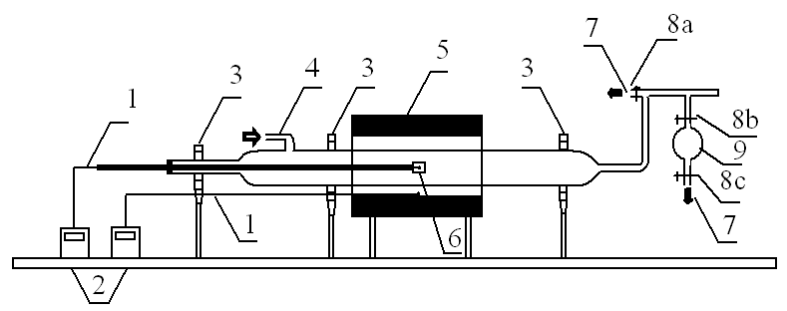

Figure 1: $\quad$ Schematic of the tube furnace (1 thermocouples, 2 temperature controller, 3 bearing, 4 nitrogen injection, 5 electric furnace, 6 combustion boat, 7 air suction, 8 a-c valves, 9 gas samplers). 
conducted for three fuels: two pines (Pinus Pinaster, Pinus laricio) and a heather Erica arborea. The fuels samples were heated from 280 to $430^{\circ} \mathrm{C}$.

Gases were collected into a balloon directly attached to a gas chromatograph. At least three repetitions were carried out. The degradation gases obtained mainly consist of $\mathrm{CO}_{2}, \mathrm{CO}, \mathrm{CH}_{4}, \mathrm{H}_{2} \mathrm{O}$, and lower amounts of hydrocarbons (Table 1).

Table 1: Mass fractions of the main pyrolysis gases released by the degradation of the vegetative fuels $(x=6$ or 8 and $y=6,8$ or 10$)$.

\begin{tabular}{|c|c|c|c|}
\hline Gas & Pinus laricio & Pinus pinaster & Erica arborea \\
\hline $\mathrm{CO}$ & 0.140 & 0.257 & 0.141 \\
\hline $\mathrm{CH}_{4}$ & 0.040 & 0.078 & 0.026 \\
\hline $\mathrm{H}_{2} \mathrm{O}$ & 0.074 & 0.047 & 0.047 \\
\hline $\mathrm{CO}_{2}$ & 0.616 & 0.536 & 0.718 \\
\hline $\mathrm{C}_{2} \mathrm{H}_{4}$ & 0.008 & 0.010 & 0.004 \\
\hline $\mathrm{C}_{2} \mathrm{H}_{6}$ & 0.015 & 0.016 & 0.005 \\
\hline $\mathrm{C}_{3} \mathrm{H}_{\mathrm{x}}$ & 0.016 & 0.008 & 0.007 \\
\hline $\mathrm{C}_{4} \mathrm{H}_{\mathrm{y}}$ & 0.090 & 0.048 & 0.052 \\
\hline
\end{tabular}

\subsection{Combustion of degradation gases in perfectly stirred conditions}

\subsubsection{The perfectly stirred reactor}

The combustion of a gas mixture representative of the degradation gases of Pinus pinaster was investigated with a PSR. To simplify the study, we only considered $\mathrm{CO}, \mathrm{CH}_{4}$ and $\mathrm{CO}_{2}$. The experimental device is composed of a reactor, a sampling system and a chromatographic system. It was applied for the first

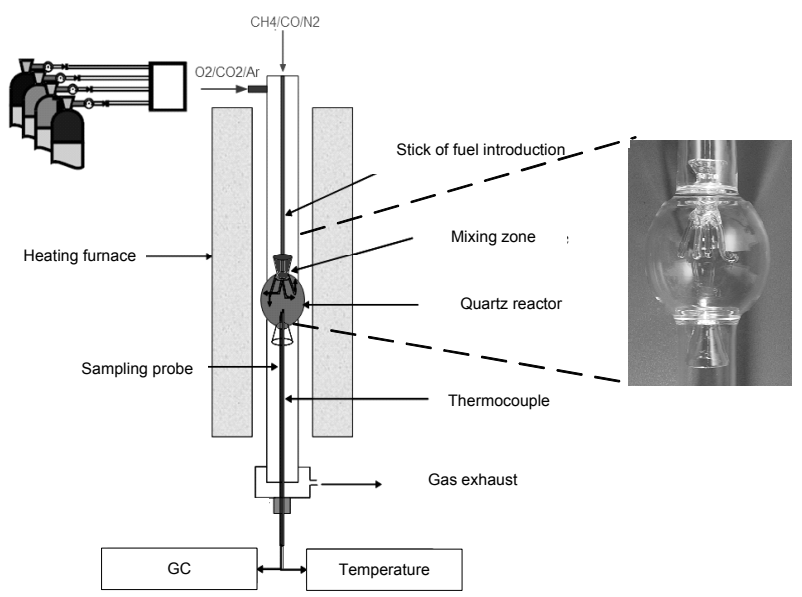

Figure 2: $\quad$ The perfectly stirred reactor. 
time for mixtures encountered in wildland fires. The reactor consists of a small sphere of $60 \mathrm{~mm}$ diameter (see fig. 2) with four nozzles $(0.3 \mathrm{~mm}$ i.d.) for the admission of gases to achieve the stirring. All the gases were preheated before injection to minimize temperature gradients into the PSR. A regulated heating furnace maintained the reactor at the desired temperature. The oxidizer and the fuel flowed separately until they reached the mixing point.

To ensure a low temperature elevation in the reactor, the reactants were diluted with a dilution factor of 9.2 from the composition obtained with the tubular furnace. The present experiments were performed at steady state for a residence time $\tau$ of $1.3 \mathrm{~s}$. The temperature of the gases in the PSR was varied stepwise in the range: $773 \mathrm{~K}-1273 \mathrm{~K}$. Samples of the reacting mixture were analyzed by gas chromatography to measure $\mathrm{H}_{2}, \mathrm{O}_{2}, \mathrm{CO}, \mathrm{CH}_{4}, \mathrm{C}_{2} \mathrm{H}_{2}, \mathrm{C}_{2} \mathrm{H}_{4}$, $\mathrm{C}_{2} \mathrm{H}_{6}$, and $\mathrm{CO}_{2}$.

\subsubsection{Kinetics modelling}

The PSR code from CHEMKIN II package [4] was used with the full mechanisms Gri Mech 3.0 [5] to model the combustion of the mixture. The species conservation equation and the conservation of energy are given by:

$$
\begin{gathered}
\dot{m}\left(Y_{k}-Y_{k}^{*}\right)-\dot{\omega}_{k} W_{k} V=0 \\
\dot{m} \sum_{k=1}^{K}\left(Y_{k} h_{k}-Y_{k}^{*} h_{k}^{*}\right)+Q=0
\end{gathered}
$$

where subscript $k$ is set for species $k$ and $K, Y, W, \dot{\omega}, h, V, Q$ and $\dot{m}$ represent respectively the species number, mass fraction, molecular weight, volumetric molar rate of reaction, specific enthalpy, reactor volume, heat loss and mass flow rate. The inlet data are marked with an *. For each reaction, the forward and backward rate coefficients are in the modified Arrhenius form. Figure 3 displays the predicted and measured molar fraction for $\mathrm{CO}$ and $\mathrm{CH}_{4}$.
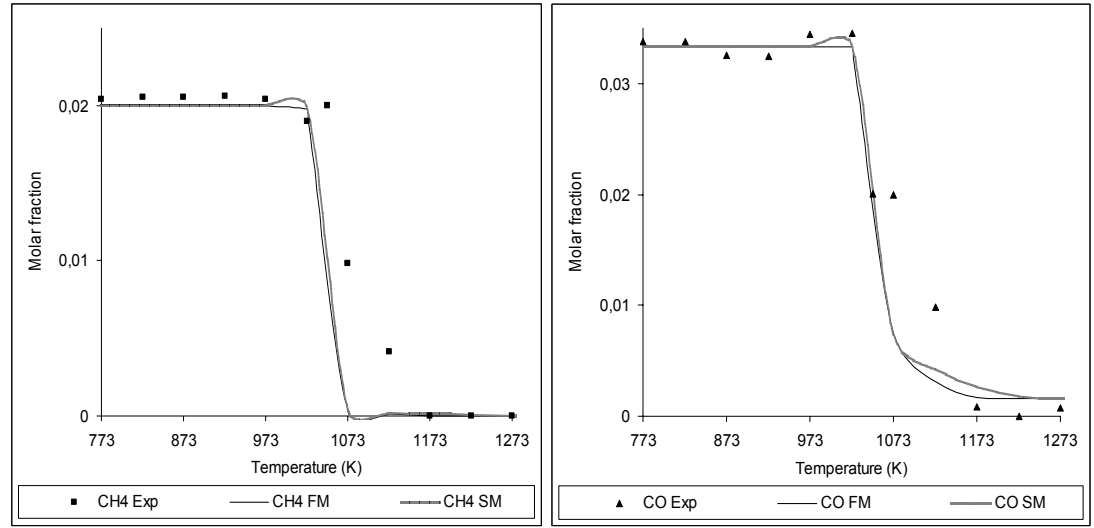

Figure 3: Experimental data and PSR code output with Full and Skeletal Mechanisms (FM and SM) for $\mathrm{CH} 4$ and $\mathrm{CO}$. 
Table 2: $\quad$ Skeletal mechanism.

\begin{tabular}{|c|c|c|c|}
\hline Reactions & $\mathrm{A}(\mathrm{mol} . \mathrm{cm} . \mathrm{s})$ & $\beta$ & $\mathrm{E}(\mathrm{cal} / \mathrm{mol})$ \\
\hline 1. $\mathrm{O}+\mathrm{H}_{2}<=>\mathrm{H}+\mathrm{OH}$ & $3.87 \mathrm{E}+04$ & 2.7 & 6260.0 \\
\hline 2. $\mathrm{O}+\mathrm{HO}_{2}<=>\mathrm{OH}+\mathrm{O}_{2}$ & $2.00 \mathrm{E}+13$ & 0.0 & 0.0 \\
\hline 3. $\mathrm{O}+\mathrm{CH}_{4}<=>\mathrm{OH}+\mathrm{CH}_{3}$ & $1.02 \mathrm{E}+09$ & 1.5 & 8600.0 \\
\hline 4. $\mathrm{O}+\mathrm{CH}_{3}<=>\mathrm{H}+\mathrm{CH}_{2} \mathrm{O}$ & $5.06 \mathrm{E}+13$ & 0.0 & 0.0 \\
\hline 5. $\mathrm{O}+\mathrm{CH}_{2} \mathrm{O}<=>\mathrm{OH}+\mathrm{HCO}$ & $3.96 \mathrm{E}+13$ & 0.0 & 3540.0 \\
\hline $6.2 \mathrm{O}+\mathrm{M}<=>\mathrm{O}_{2}+\mathrm{M}^{\mathrm{a}}$ & $1.20 \mathrm{E}+17$ & -1.0 & 0.0 \\
\hline 7. $\mathrm{H}+\mathrm{O}_{2}<=>\mathrm{O}+\mathrm{OH}$ & $2.65 \mathrm{e}+16$ & -0.7 & 17041.0 \\
\hline 8. $\mathrm{H}+\mathrm{O}_{2}+\mathrm{H}_{2} \mathrm{O}<=>\mathrm{HO}_{2}+\mathrm{H}_{2} \mathrm{O}$ & $1.13 \mathrm{E}+19$ & -0.8 & 0.0 \\
\hline 9. $\mathrm{H}+\mathrm{O}_{2}+\mathrm{AR}<=>\mathrm{HO}_{2}+\mathrm{AR}$ & $7.00 \mathrm{E}+17$ & 0.8 & 0.0 \\
\hline 10. $\mathrm{H}+\mathrm{O}_{2}+\mathrm{N}_{2}<\Rightarrow \mathrm{HO}_{2}+\mathrm{N}_{2}$ & $2.60 \mathrm{E}+19$ & -1.2 & 0.0 \\
\hline 11. $\mathrm{H}+2 \mathrm{O}_{2}<=>\mathrm{HO}_{2}+\mathrm{O}_{2}$ & $2.08 \mathrm{E}+19$ & -1.2 & 0.0 \\
\hline 12. $\mathrm{H}+\mathrm{HO}_{2}<=>2 \mathrm{OH}$ & $8.40 \mathrm{E}+13$ & 0.0 & 635.0 \\
\hline 13. $\mathrm{H}+\mathrm{HO}_{2}<=>\mathrm{O}_{2}+\mathrm{H}_{2}$ & $4.48 \mathrm{E}+13$ & 0.0 & 1068.0 \\
\hline 14. $\mathrm{H}+\mathrm{CH}_{4}<=>\mathrm{CH}_{3}+\mathrm{H}_{2}$ & $6.60 \mathrm{E}+08$ & 1.6 & 10840.0 \\
\hline 15. $\mathrm{H}+\mathrm{CH}_{2} \mathrm{O}<=>\mathrm{HCO}+\mathrm{H}_{2}$ & $5.74 \mathrm{E}+07$ & 1.9 & 2742.0 \\
\hline 16. $\mathrm{H}+\mathrm{O}_{2}+\mathrm{M}<=>\mathrm{HO}_{2}+\mathrm{M}$ & $2.80 \mathrm{E}+18$ & -0.9 & 0.0 \\
\hline 17. $\mathrm{H}+\mathrm{CH}_{2} \mathrm{O}(+\mathrm{M})<=>\mathrm{CH}_{3} \mathrm{O}$ & $5.40 \mathrm{E}+11$ & 0.5 & 2600.0 \\
\hline 18. $\mathrm{H}+\mathrm{CH}_{3}(+\mathrm{M})<=>\mathrm{CH}_{4}(+\mathrm{M})$ & $1.39 \mathrm{E}+16$ & -0.5 & 536.0 \\
\hline 19. $2 \mathrm{OH}<=>\mathrm{O}+\mathrm{H}_{2} \mathrm{O}$ & $3.57 \mathrm{E}+04$ & 2.4 & -2110.0 \\
\hline 20. $\mathrm{OH}+\mathrm{H}_{2}<=>\mathrm{H}+\mathrm{H}_{2} \mathrm{O}$ & $2.16 \mathrm{E}+08$ & 1.5 & 3430.0 \\
\hline 21. $\mathrm{OH}+\mathrm{HO}_{2}<=>\mathrm{O}_{2}+\mathrm{H}_{2} \mathrm{O}$ & $1.45 \mathrm{E}+13$ & 0.0 & -500.0 \\
\hline 22. $\mathrm{OH}+\mathrm{CH}_{4}<=>\mathrm{CH}_{3}+\mathrm{H}_{2} \mathrm{O}$ & $1.00 \mathrm{E}+08$ & 1.6 & 3120.0 \\
\hline 23. $\mathrm{OH}+\mathrm{CH}_{2} \mathrm{O}<=>\mathrm{HCO}+\mathrm{H}_{2} \mathrm{O}$ & $3.43 \mathrm{E}+09$ & 1.2 & -447.0 \\
\hline 24. $\mathrm{OH}+\mathrm{CO}<=>\mathrm{H}+\mathrm{CO}_{2}$ & $4.76 \mathrm{E}+07$ & 1.2 & 70.0 \\
\hline 25. $\mathrm{HO}_{2}+\mathrm{CH}_{3}<=>\mathrm{O}_{2}+\mathrm{CH}_{4}$ & $1.00 \mathrm{E}+13$ & 0.0 & 0.0 \\
\hline 26. $\mathrm{HO}_{2}+\mathrm{CH}_{3}<=>\mathrm{OH}+\mathrm{CH}_{3} \mathrm{O}$ & $3.78 \mathrm{E}+13$ & 0.0 & 0.0 \\
\hline 27. $\mathrm{HO}_{2}+\mathrm{CO}<=>\mathrm{OH}+\mathrm{CO}_{2}$ & $1.50 \mathrm{E}+14$ & 0.0 & 23600.0 \\
\hline 28. $\mathrm{O}_{2}+\mathrm{CH}_{2} \mathrm{O}<=>\mathrm{HO}_{2}+\mathrm{HCO}$ & $1.00 \mathrm{E}+14$ & 0.0 & 40000.0 \\
\hline 29. $\mathrm{O}_{2}+\mathrm{CO}<=>\mathrm{O}+\mathrm{CO}_{2}$ & $2.50 \mathrm{E}+12$ & 0.0 & 47800.0 \\
\hline 30. $\mathrm{HCO}+\mathrm{O}_{2}<=>\mathrm{HO}_{2}+\mathrm{CO}$ & $1.35 \mathrm{E}+13$ & 0.0 & 400.0 \\
\hline 31. $\mathrm{HCO}+\mathrm{M}<=>\mathrm{H}+\mathrm{CO}+\mathrm{M}$ & $1.87 \mathrm{E}+17$ & -1.0 & 17000.0 \\
\hline 32. $\mathrm{HCCO}+\mathrm{O}_{2}<=>\mathrm{OH}+2 \mathrm{CO}$ & $3.20 \mathrm{E}+12$ & 0.0 & 854.0 \\
\hline 33. $\mathrm{CH}_{3}+\mathrm{O}_{2}<=>\mathrm{O}+\mathrm{CH}_{3} \mathrm{O}$ & $3.56 \mathrm{E}+13$ & 0.0 & 30480.0 \\
\hline 34. $\mathrm{CH}_{3}+\mathrm{O}_{2}<=>\mathrm{OH}+\mathrm{CH}_{2} \mathrm{O}$ & $2.31 \mathrm{E}+12$ & 0.0 & 20315.0 \\
\hline 35. $\mathrm{CH}_{3}+\mathrm{CH}_{2} \mathrm{O}<=>\mathrm{HCO}+\mathrm{CH}_{4}$ & $3.32 \mathrm{E}+03$ & 2.8 & 5860.0 \\
\hline 36. $\mathrm{CH}_{3} \mathrm{O}+\mathrm{O}_{2}<=>\mathrm{HO}_{2}+\mathrm{CH}_{2} \mathrm{O}$ & $4.28 \mathrm{E}-13$ & 7.6 & -3530.0 \\
\hline 37. $2 \mathrm{CH}_{3}(+\mathrm{M})<=>\mathrm{C}_{2} \mathrm{H}_{6}(+\mathrm{M})$ & $6.77 \mathrm{E}+16$ & -1.2 & 654.0 \\
\hline 38. $\mathrm{O}+\mathrm{C}_{2} \mathrm{H}_{6}<=>\mathrm{OH}+\mathrm{C}_{2} \mathrm{H}_{5}$ & $8.98 \mathrm{E}+07$ & 1.9 & 5690.0 \\
\hline 39. $\mathrm{H}+\mathrm{C}_{2} \mathrm{H}_{6}<=>\mathrm{C}_{2} \mathrm{H}_{5}+\mathrm{H}_{2}$ & $1.15 \mathrm{E}+08$ & 1.9 & 7530.0 \\
\hline 40. $\mathrm{OH}+\mathrm{C}_{2} \mathrm{H}_{6}<=>\mathrm{C}_{2} \mathrm{H}_{5}+\mathrm{H}_{2} \mathrm{O}$ & $3.54 \mathrm{E}+06$ & 2.1 & 870.0 \\
\hline 41. $\mathrm{CH}_{3}+\mathrm{C}_{2} \mathrm{H}_{6}<=>\mathrm{C}_{2} \mathrm{H}_{5}+\mathrm{CH}_{4}$ & $6.14 \mathrm{E}+06$ & 1.7 & 10450.0 \\
\hline 42. $\mathrm{C}_{2} \mathrm{H}_{5}+\mathrm{O}_{2}<=>\mathrm{HO}_{2}+\mathrm{C}_{2} \mathrm{H}_{4}$ & $8.40 \mathrm{E}+11$ & 0.0 & 3875.0 \\
\hline 43. $\mathrm{H}+\mathrm{C}_{2} \mathrm{H}_{4}(+\mathrm{M})<=>\mathrm{C}_{2} \mathrm{H}_{5}(+\mathrm{M})$ & $5.40 \mathrm{E}+11$ & 0.5 & 1820.0 \\
\hline
\end{tabular}


Table 2: $\quad$ Continued.

\begin{tabular}{|l|c|c|c|}
\hline $44 . \mathrm{OH}+\mathrm{C}_{2} \mathrm{H}_{4}<=>\mathrm{C}_{2} \mathrm{H}_{3}+\mathrm{H}_{2} \mathrm{O}$ & $3.60 \mathrm{E}+06$ & 2.0 & 2500.0 \\
\hline $45 . \mathrm{CH}_{3}+\mathrm{C}_{2} \mathrm{H}_{4}<=>\mathrm{C}_{2} \mathrm{H}_{3}+\mathrm{CH}_{4}$ & $2.27+05$ & 2.0 & 9200.0 \\
\hline $46 . \mathrm{C}_{2} \mathrm{H}_{3}+\mathrm{O}_{2}<=>\mathrm{HO}_{2}+\mathrm{C}_{2} \mathrm{H}_{2}$ & $1.34 \mathrm{E}+06$ & 1.6 & -384.0 \\
\hline $47 . \mathrm{H}+\mathrm{C}_{2} \mathrm{H}_{2}(+\mathrm{M})<=>\mathrm{C}_{2} \mathrm{H}_{3}(+\mathrm{M})$ & $5.60 \mathrm{E}+12$ & 0.0 & 2400.0 \\
\hline $48 . \mathrm{O}+\mathrm{C}_{2} \mathrm{H}_{2}<=>\mathrm{H}+\mathrm{HCCO}$ & $1.35 \mathrm{E}+07$ & 2.0 & 1900.0 \\
\hline $49 . \mathrm{O}+\mathrm{C}_{2} \mathrm{H}_{4}<=>\mathrm{CH}_{3}+\mathrm{HCO}$ & $1.25 \mathrm{E}+07$ & 1.8 & 220.0 \\
\hline
\end{tabular}

The third-body efficiencies are $\mathrm{Z}\left(\mathrm{H}_{2}\right)=2 ; \mathrm{Z}\left(\mathrm{H}_{2} \mathrm{O}\right)=6 ; \mathrm{Z}\left(\mathrm{CH}_{4}\right)=2 ; \mathrm{Z}(\mathrm{CO})=1.5$; $\mathrm{Z}\left(\mathrm{CO}_{2}\right)=2 ; \mathrm{Z}\left(\mathrm{C}_{2} \mathrm{H}_{6}\right)=3 ; \mathrm{Z}(\mathrm{Ar})=0.7$.

We can note a general agreement. The most important reactions for the combustion were retained in the skeletal mechanism, which was derived from the full mechanism through sensitivity analysis. It is listed in Table 2 and involves 22 species and 49 reactions. The initiation reaction is R6. The oxidation of hydrogen and formation of radicals is due to R1, R2, R7-13, R16 and R19-21. The carbon monoxide is oxidized by R24, R27 and R29. The methane break-up occurs through R3, R14, R18, R22 and R25. Then the $\mathrm{C}_{1}$-chain continues toward $\mathrm{CH}_{3} \mathrm{O}$ and $\mathrm{CH}_{2} \mathrm{O}$ via R4, R17, R26, R33-36. $\mathrm{CH}_{2} \mathrm{O}$ forms $\mathrm{HCO}$ by R5, R15, R23 and $\mathrm{R} 28$. HCO radical is converted in $\mathrm{CO}$ mainly by $\mathrm{R} 30$ and $\mathrm{R} 31$. The $\mathrm{C} 2$-chain is activated by $\mathrm{R} 37$ and $\mathrm{R} 49$. Then $\mathrm{C}_{2} \mathrm{H}_{6}$ is converted to $\mathrm{C}_{2} \mathrm{H}_{2}$ through $\mathrm{R} 38-47$. $\mathrm{C}_{2} \mathrm{H}_{2}$ forms HCCO by $\mathrm{R} 48$ and HCCO is converted to $\mathrm{CO}$ by $\mathrm{R} 32$.

\section{From skeletal to global models}

\subsection{Laminar flames from vegetative fuels}

The skeletal mechanism was tested with laminar diffusion flame of crushed vegetative fuels. Crushing allows obtaining laminar flame and avoiding fuel geometries effects on the burning. The experimental device is given in fig. 4 .

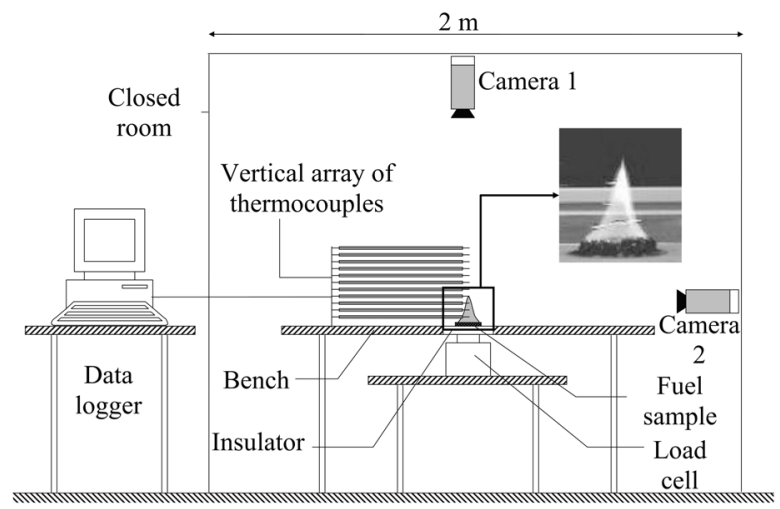

Figure 4: $\quad$ Sketch of the experimental apparatus. 
The fuel sample was in the shape of a cylinder (diameter of $3.5 \mathrm{~cm}$, depth of 5 $\mathrm{mm}$ and mass of $1.5 \mathrm{~g}$ ). The mass loss was measured. Ignition was performed with ethanol. 11 thermocouples (type K, wires $50 \mu \mathrm{m}$ ) were positioned along the flame axis. Five repetitions were made. During the first $60 \mathrm{~s}$ of the burning, the flame fluctuates then it becomes laminar. Its height decreases from 4 to $1.5 \mathrm{~cm}$ and after $120 \mathrm{~s}$, the extinction begins.

\subsection{Balance equations and kinetics modelling}

The crushed sample was represented by a burner. The model solved the twodimensional, unsteady, laminar, reactive Navier-Stokes equations coupled with radiation and transport. The flow was calculated using a finite-volume procedure and radiative transfer equation was solved with the discrete ordinates method.

$$
\begin{gathered}
\frac{\partial \rho}{\partial t}+\vec{\nabla} \rho \vec{V}=0 \\
\frac{\partial \rho Y_{i}}{\partial t}+\rho \vec{V} \cdot \vec{\nabla} Y_{i}=\vec{\nabla}\left(\rho D_{i j} \vec{\nabla} Y_{i}\right)+\dot{\omega}_{i} \\
\frac{\partial \rho \vec{V}}{\partial t}+\rho \vec{V} \vec{\nabla} \cdot \vec{V}=\vec{\nabla} p+\rho \vec{g}+\vec{\nabla} \cdot \overline{\bar{\tau}} \\
\frac{\partial \rho e}{\partial t}+\rho \vec{V} \cdot \vec{\nabla} e=\vec{\nabla}(\lambda \vec{\nabla} T)+\vec{\nabla} \cdot \overrightarrow{R_{g}}+\vec{\nabla}\left(\rho \sum_{i=1}^{N} h_{i} D_{i j} \vec{\nabla} Y_{i}\right)-\vec{\nabla} \cdot(p \vec{V})+\vec{\nabla} \cdot(\overline{\bar{\tau}} \cdot \vec{V})+\dot{Q} \\
\frac{d I(\vec{r}, \vec{s})}{d s}+a I(\vec{r}, \vec{s})=a \frac{\sigma T^{4}}{\pi}
\end{gathered}
$$

Five mechanisms were tested to model the combustion:

a. The skeletal mechanism previously presented (49 reactions, 22 species).

b. The skeletal mechanism of [10] for methane (23 reactions, 14 species).

c. The skeletal mechanism of [7] for wildland fire (22 reactions, 14 species).

$\mathrm{d}$. The global mechanism (GM1) which considers only $\mathrm{CO}$ as fuel

$$
\begin{gathered}
\mathrm{CO}+0.5 \mathrm{O}_{2} \Leftrightarrow \mathrm{CO}_{2} \\
\dot{\omega}_{\mathrm{CO}}=2.23910^{12}[\mathrm{CO}]\left[\mathrm{H}_{2} \mathrm{O}\right]^{0.5}\left[\mathrm{O}_{2}\right]^{0.25} \exp \left[-\frac{1.310^{8}}{R . T}\right] \\
\dot{\omega}_{\mathrm{CO}_{2}}=510^{8}\left[\mathrm{CO}_{2}\right] \exp \left[-\frac{1.310^{8}}{R . T}\right]
\end{gathered}
$$

- The global mechanism (GM2) for which the oxidation of $\mathrm{CO}$ is given by eqns. (8-10) and the oxidation of $\mathrm{CH}_{4}$ is incomplete.

$$
\begin{gathered}
\mathrm{CH}_{4}+1.5 \mathrm{O}_{2} \Rightarrow \mathrm{CO}+2 \mathrm{H}_{2} \mathrm{O} \\
\dot{\omega}_{\mathrm{CH}_{4}}=5.01210^{11}\left[\mathrm{CH}_{4}\right]^{0.7}\left[\mathrm{O}_{2}\right]^{0.8} \exp \left[-\frac{210^{8}}{R . T}\right]
\end{gathered}
$$


The evaluation of these models was carried out based on their computational time and their accuracy against the experimental results of laminar flame from Pinus laricio samples at $60 \mathrm{~s}$ (the beginning of the laminar stage of the flame).

\subsection{Composition of the gas mixture}

Our skeletal mechanism was used to test whether the $\mathrm{C}_{2}$ hydrocarbons have to be taken into account for the modelling of the laminar flame. Two mixtures were tested. For mixture 1, the mass fractions of $\mathrm{CO}, \mathrm{H}_{2} \mathrm{O}, \mathrm{CH}_{4}$ and $\mathrm{C}_{2}$ hydrocarbons are given in Table 1 while for mixture $2, \mathrm{C}_{2}$ were omitted. For both mixtures, the mass fraction of $\mathrm{CO}_{2}$ is taken to set the sum of all mass fractions equals to 1 . Table 3 gives the conditions at the burner.

Table 3: $\quad$ Burner inputs for the determination of the gas composition.

\begin{tabular}{|c|c|c|}
\hline & Mixture 1 & Mixture 2 \\
\hline $\mathrm{CO}$ & 0.140 & 0.140 \\
\hline $\mathrm{CH}_{4}$ & 0.040 & 0.040 \\
\hline $\mathrm{H}_{2} \mathrm{O}$ & 0.074 & 0.074 \\
\hline $\mathrm{CO}_{2}$ & 0.722 & 0.746 \\
\hline $\mathrm{C}_{2} \mathrm{H}_{4}$ & 0.008 & - \\
\hline $\mathrm{C}_{2} \mathrm{H}_{6}$ & 0.015 & - \\
\hline Mass flow rate (kg.s $\left.{ }^{-1}\right)$ & \multicolumn{2}{|c|}{$4.4710^{-6}$} \\
\hline Radius (cm) & \multicolumn{2}{|c|}{1.47} \\
\hline
\end{tabular}

Figure 5 displays the comparison between predicted and observed temperatures along the flame axis. The range of experimental temperatures is represented by vertical lines. The results computed with mixture 1 overestimate the temperatures while results obtained with mixture 2 match the experiments. In the thermal plume, the predictions are slightly higher. The thermal plume

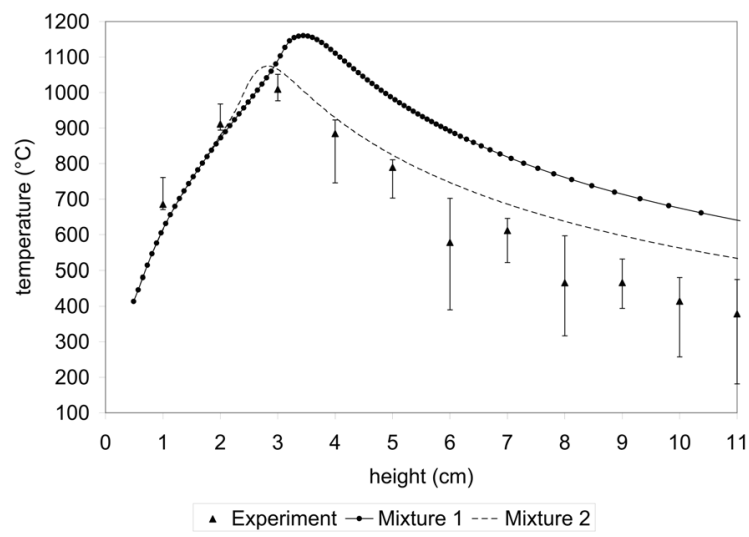

Figure 5: Comparison between observed and predicted temperatures with our skeletal mechanism and two mixtures, along the flame axis. 
becomes progressively turbulent with height and the cooling due to the mixing with air is underestimated for laminar simulation. According to these results, to match experiments, one has to consider the mass fractions of $\mathrm{CO}, \mathrm{CH}_{4}$ and $\mathrm{H}_{2} \mathrm{O}$ obtained during the gas analysis and to neglect other species.

\subsection{Test of other skeletal and global models}

Since our mechanism is time consuming (about 1 week on our workstation), other skeletal mechanism from [2] and [6] were tested. Figure 6 presents a comparison of the three skeletal mechanisms along the flame axis. The temperature curves are similar. The mechanism elaborated by [2] generates however higher temperatures than the others. In the flame zone, the temperatures predicted by the mechanism of [6] are in the range of the experimental data with a reduced computational time. However, the computational time remains too long (twice the duration required to compute the flow field without reaction).

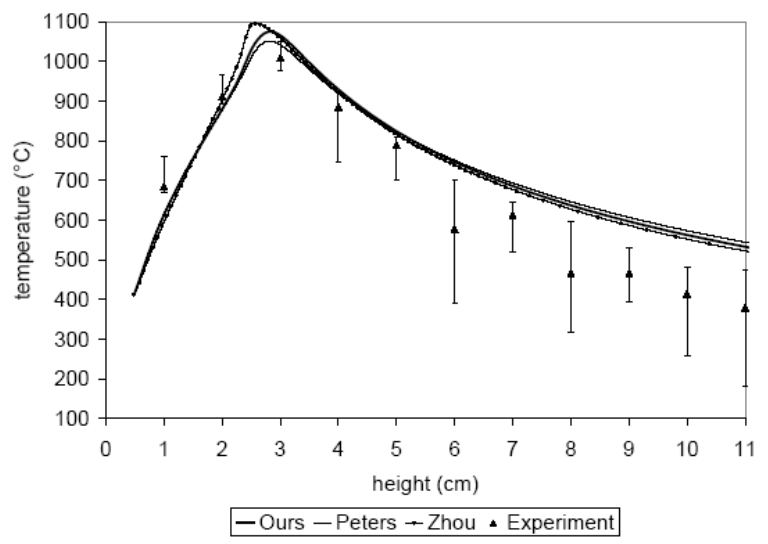

Figure 6: Comparison between observed and predicted temperatures obtained with our skeletal mechanism and that of Zhou [2] and Peters [6].

Thus global mechanisms were examined. Mixture 2 (see Table 3) was used to test mechanism GM2. Since GM1 does not consider methane, two compositions called mixture 3 and 4 and derived from mixture 2 were used (see Table 4).

Table 4: $\quad$ Burner inputs for the determination of the global mechanism.

\begin{tabular}{|c|c|c|c|}
\hline Composition & Mixture 2 & Mixture 3 & Mixture 4 \\
\hline Mechanism & GM2 and [10]. & \multicolumn{2}{|c|}{ GM1 } \\
\hline $\mathrm{CO}$ & 0.140 & 0.180 & 0.338 \\
\hline $\mathrm{CH}_{4}$ & 0.040 & - & - \\
\hline $\mathrm{H}_{2} \mathrm{O}$ & 0.074 & 0.074 & 0.074 \\
\hline $\mathrm{CO}_{2}$ & 0.746 & 0.746 & 0.588 \\
\hline $\mathrm{LHV}(\mathrm{MJ} / \mathrm{kg})$ & 3.42 & 1.82 & 3.42 \\
\hline
\end{tabular}


Mixture 3 was established according to Grishin's hypothesis [3] for which the mass fraction of $\mathrm{CO}$ is set equal to the sum of $\mathrm{CO}$ and $\mathrm{CH}_{4}$. In mixture 4 , the mass fraction of $\mathrm{CO}$ is taken to give the same low heating value as mixture 2 . Figure 7 shows the experimental and simulated temperatures along the flame axis obtained with these global mechanisms and the skeletal mechanism of [6]. GM1 with mixture 3 underestimates significantly the temperature (about $200^{\circ} \mathrm{C}$ ). The energy released is too low. The association of mixture 4 with mechanism GM1 provides better results. However, the position of the maximum temperature gives an error of $25 \%$. Conversely, mechanism GM2 matches the experimental temperatures and predictions of skeletal mechanism from [6]. Moreover the computational time with GM2 is equal to the calculation time for the cold flow. It meets the criteria of accuracy and computational time required for the definition of a combustion model usable in forest fire simulation.

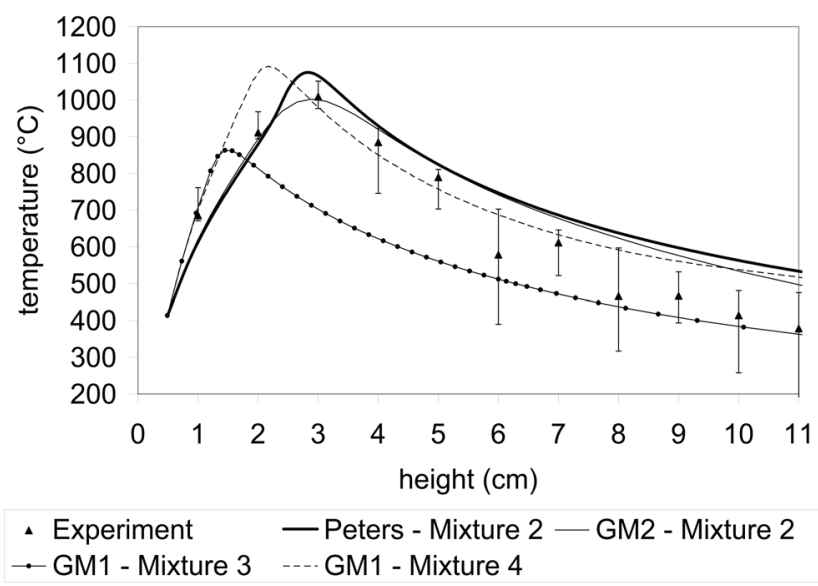

Figure 7: $\quad$ Experimental and computed temperatures obtained with the global mechanisms and Peters and Kee's mechanism along the flame axis.

\section{Conclusion}

The main contributions of this work can be summarized as follow:

- The gases released during the degradation of forest fuels were identified,

- Their combustion was studied with a PSR leading to the elaboration of a skeletal mechanism including the $\mathrm{C}_{2}$,

- This mechanism was validated for a diffusion laminar flame,

- A global mechanism including methane for combustion was proposed.

Prospects will concern the test of this global mechanism under turbulent condition at laboratory and field scales. 


\section{References}

[1] Pastor, E., Zarate, L., Planas, E. \& Arnaldos, J., Mathematical models and calculation systems for the study of wildland fire behaviour. Progress in energy and combustion science, 29, pp. 139-153 2003.

[2] Zhou, X. \& Mahalingam, S., Evaluation of reduced mechanism for modelling combustion of pyrolysis gas in wildland fire. Combustion Science and Technology, 171, pp. 39-70, 2001.

[3] Grishin, A.M., Mathematical modeling of forest fires and new methods of fighting them, Publishing House of Tomsk University: Tomsk, 390 p, 1997.

[4] Kee, R.J., Rupley, F.M. \& Miller, J.A., Chemkin-II: A FORTRAN Chemical Kinetics Package for the Analysis of Gas-Phase Chemical Kinetics, Report No. SAND 89-8009: Sandia National Laboratories, 1989.

[5] Gri-Mech http://www.me.berkeley.edu/gri_mech/

[6] Peters, N. \& Kee, R. J., The computation of stretched laminar methane-air diffusion flames using a reduced four step mechanism, Combustion and Flame, 68, pp. 17-29, 1987. 